Int. Arch. Allergy 1968;33:I-VII

\title{
Contents, Vol. 33, 1968
}

International Archives of

Allergy and Applied Immunology

Incorporating the Transactions of the Collegium Internationale

AUergologicum and the Proceedings of the International Association

of Asthmology and of National Allergy Societies

Editors-in-Chief

R. R. A. Coombs, Cambridge

H. C. Goodman, Geneva

F. Hahn, Freiburg/Br.

D. Harley, London

P. Kallós, Helsingborg

F. Milgrom, Buffalo, N.Y.

G. B. West, Carshalton, Surrey

Contributing Editors

E. L. Becker, Washington, D.C.

H. Bloch, Basel

C. J. C. Britton, London

W. E. Brocklehurst, Edinburgh

T. Broman, Göteborg

L. Businco, Roma

A. Cerletti, Basel

A. L. De Weck, Bern

J. Duchaine, Bruxelles

G. Estrada De La Riva, Havana

P. G. H. Gell, Birmingham

I. Glazer, Tel Aviv

R. A. Good, Minneapolis, Minn.

W. Gronemeyer, Bad Lippspringe
A. Grumbach Zurich
B. Halpern, Paris

T. Inderbitzin, Boston, Mass.

H. Isliker, Lausanne

E. A. Kabat, New York

W. Kaufman, Bridgeport, Conn.

R. Keller, Zurich

J. Lecomte, Liège

J. R. Marrack, Cambridge

J. A. Moretti, Montevideo 
T. Ogata, Tokyo

A. Oliveira-Lima, Rio de Janeiro

D. Ordman, Johannesburg

Ö. Ouchterlony, Göteborg

W. Pagel, London

R. Panzani, Marseille

C. Rimington, London

M. Rocha E Silva, São Paulo

I. M. Roitt, London

B. Rose, Montreal

G. Ruiz Moreno, Buenos Aires

J. Runnström, Stockholm

E. Sorkin, Davos-Platz

A. Stoll, Basel

H. Storck, Zurich

A. Tiselius, Uppsala

Z. Trnka, Geneva

B. H. Waksman, New Haven, Conn.

G. L. Waldbott, Detroit, Mich.

R. G. White, London

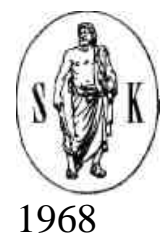

Vol. 33

BASEL (Switzerland) S. KARGER NEW YORK

All rights, including that of translation into other languages, reserved.

Photomechanic reproduction (photocopy, microcopy) of this book or parts thereof without special permission of the publishers is prohibited.

(c)

Copyright 1968 by S. Karger AG, Basel Printed in Switzerland by Buchdruckerei NationalZeitung AG, Basel

Contents

Ablin, R.J. and Beutner, E.H. (Buffalo, N.Y.): Absorption Studies in An

tigen (s) of the Esophageal Mucosa Reactive with Autoantibodies of

Pemphigus 227

Aguirre, A.: vide Katsh, S.

Albert, U.: vide Giertz, $\mathrm{H}$.

Andrzejewski, C. Z.: vide Haferkamp, O.

Arora, S. and Sanyal, R. K. (New Delhi): The Role of the Adrenergic System

in the Mechanism of Action of Bordetella pertussis Vaccine 299

Barboriak, J.J.; Fink, J.N. and Scribner, Gertrude, H. (Wood, Wis.): Anti-

genic Specificity in a Hypersensitivity Pneumonitis 473

Bernstein, I.D. and Ovary, Z. (New York, N.Y.): Absorption of Antigens from

the Gastrointestinal Tract . 521 
Beutner, E.H.: vide Ablin, R.J.

Beutner, E. H.: vide Hjort, T.

Blazkovec, A.A. (Madison, Wis.); Hulliger, L. (Basel) and Sorkin, E.

(Davos-Platz): A Study of the Passive Cellular Transfer of Local Cutan

eous Hypersensitivity. III. Transfer of Hypersensitivity to Sheep Erythro-

cytes with Different Cell Types 259

Blazkovec, A.A.: vide Hulliger, L.

Blennerhassett, J. B.: vide Naspitz, C. K.

Bonavida, B.: vide Sapse, A.T.

Borel, Yves (Boston, Mass.); Fauconnet, Marthe (New York, N.Y.) and Miescher, P.A.

(Geneva): The Effect of 6-Mercaptopurine (6-MP) and Methotrexate (MTX) on Passive Delayed

Hypersensitivity Reactions 583

Braun, D.: vide Holm, S. E.

Bültmann, B.: vide Haferkamp, O.

Castrova, Alexandra; Pekárek, J. and Johanovský, J. (Prague): Study of

Systemic Fever Reaction of the Delayed Type Hypersensitivity. III. Some

Conditions of the Release of a Pyrogenic Substance during the Cultivation

of Blood Cells with Specific Antigen in vitro

313

Cooper, M.D.; Perey, D.Y.; Gabrielsen, Ann E.; Sutherland, D.E.R.;

McKneally, M.F. and Good, R.A. (Minneapolis, Minn.): Production

of an Antibody Deficiency Syndrome in Rabbits by Neonatal Removal of

Organized Intestinal Lymphoid Tissues

65

Cortese, T.A.: vide Layton, L. L.

Csaba, B. and West, G. B. (London): The Effect of Temperature and Some

Antagonistic Drugs on Anaphylactic Shock in the Rat 99

Eisen, A.H.: vide Naspitz, C.K.

Elves, M.W. (Oswestry, Shrops.): On the Mechanism of Action of Phyto-

haemagglutinin on Immunological Reactions 353

Contents

Fauconnet, Marthe : vide Borel, Yves

Feinberg, J. G. and Hill, Christine W. (Stoke Poges): Newer Techniques for Immunoelectrophoresis and Immunodiffusion 120

Feinberg, J.G. (Chelsea): Allergy to Antibiotics. I. Fact and Conjecture on the

Sensitizing Contaminants of Penicillins and Cephalosporins 439

Feinberg, J. G. (Chelsea): Allergy to Antibiotics. II. Comparative Immunogen-

icity of Some Penicillins 444

von Fellenberg, R. (Berne) and Rose, N.R. (Buffalo, N.Y.): Antigenicity of

Insulin 454

Field, E.J.: vide Hughes, D. Fink, J.N.: vide Barboriak, J.J.

Gabbiani, G. (Montreal): Action of Cyproheptadine on Generalized and Local

Anaphylactoid Oedema 568

Gabrielsen, Ann E.: vide Cooper, M. D.

Gewurz, H. (Bethesda, Md.); Pickering, R.J. and Good, R. A. (Minneapolis, Minn.): Complement and Complement Component Activities in Diseases

Associated with Repeated Infections and Malignancy 368 
Giertz, H.; Hahn, F.; Krull, P. and Albert, U. (Freiburg im Br.): Histaminase Liberating and Anticoagulant Activity of Heparin Released in Anaphylactic Shock in the Guinea Pig 311

Girard, J.-P. (Geneva): Common Antigenic Determinants of Penicillin G, Ampicillin and the Cephalosporins Demonstrated in Men 428

Goldfarb, A.R. and Uppin, B.I. (Detroit, Mich.): Biochemical Consequences

of the Anaphylactic Reaction. I. Oxidation of Glucose by Sensitized

Guinea Pig Heal Strips 179

Good, R.A.: vide Cooper, M.D.

Good, R.A.: vide Gewurz, H.

Goodfriend, L. and Perelmutter, L. (Montreal): Properties of Two Chromato-

graphically Distinct Reagins in the Sera of Ragweed Atopic Individuals 89

Goodfriend, L. and Luhovyj, I. (Montreal): In vitro Detection of Reagins in

Human Atopic Sera by Monkey Skin Suspension Technique 171

Grob, P.J.: vide Inderbitzin, Th. M.

Gutersohn, J.: vide de Weck, A. L.

Haferkamp, O.; Bültmann, B.; Andrzejewski, C.Z. (Bonn) and Tonutti, E. (Ulm): Experimental and Immunologic Investigations of Biologic Effects

Produced by Hormones. I. Immunofluorescent Studies of the Localization of Testosterone in Seminal Vesicles of the Rat 528

Hahn, F.: vide Giertz, $\mathrm{H}$.

Hall, H.E.: vide Johnson, H.M.

Heilman, Dorothy H. (Washington, D. C.): In vitro Toxicity of Endotoxin for Macrophages of Young Guinea Pigs and Rabbits 501

Hicks, R.; Okpako, D.T. and Leach, G.D.H. (Bradford): Factors Determining the Development of Anaphylactic Hypersensitivity in the Guinea Pig, and Their Influence on Mechanisms Involved in Desensitization 29

Hicks, R. and Okpako, D.T. (Bradford): The Influence of the Size of the Sensi tising Dose of Antigen on the Development and Duration of Anaphylactic Hypersensitivity in the Guinea Pig 131

Hill, Christine W.: vide Feinberg, J. G.

Hjort, T. (Aarhus); Beutner, E.H. and Witebsky, E. (Buffalo, N. Y.): Uptake

Contents

of Labelled Antigens by Lymphocytes of Rabbits with Delayed Hyper-

sensitivity Reactions 337

Holm, S. E.; Braun, D. and Jönsson, Jane (Göteborg): Antigenic Factors Com

mon to Human Kidney and Nephritogenic and Non-Nephritogenic

Streptococcal Strains 127

Hughes, D. and Field, E.J. (Newcastle upon Tyne): Inhibition of Macrophage

Migration in vitro by Brain and Encephalitogenic Factor in Allergic

Encephalomyelitis 45

Hulliger, L. (Basel); Blazkovec, A.A. (Madison, Wis.) and Sorkin, E. (Davos-Platz): A Study of the Passive Cellular Transfer of Local Cutaneous Hypersensitivity. IV. Transfer of Hypersensitivity to Sheep Erythro-cytes with Peritoneal Exudate Cells Passively Coated with Antibody . . 281

Hulliger, L.: vide Blazkovec, A.A. 
Humphrey, L.J.: vide Milgrom, F.

Hurtado, I. de (Caracas): Studies on the Biological Activity of Rhus striata

('Manzanillo'). II. Skin Response to Patch Test in Humans 209

Inderbitzin, Th.M. and Grob, P.J. (Boston, Mass.): Acantholysis in Pemphigus, an Immunologic Phenomenon $\quad 576$

Ivanyi, J.: vide Sapse, A.T.

Johanovský, J.: vide Castrová, Alexandra

Johnson, H.M.; Smith, B.G. and Hall, H.E. (Cincinnati, O.): Carbodiimide

Hemagglutination. A Study of Some of the Variables of the Coupling

Reaction 511

Jönsson, Jane: vide Holm, S.E.

Katsh, S. and Aguirre, A. (Denver, Col.): Biochemical Responses in Organs of

Guinea Pigs Immunized with Aspermatogenic Antigen 141

Kayser, F.-H.: vide Keller, R.

Keller, H.U.: vide Keller, R.

Keller, R. (Zurich); Mueller-Eckhardt, C. (Berne); Kayser, F.-H. (Zurich)

and Keller, H.U. (Davos-Platz): Interrelations between Different Types

of Cells. I. A Comparative Study of the Biological Properties of a Cationic

Polypeptide from Lysosomes of Polymorphonuclear Leukocytes and Other

Cationic Compounds 239

Korngold, L.: vide Madalinski, K.

Kramer, R.: vide Sapse, A.T.

Krull, P.: vide Giertz, $\mathrm{H}$.

Laddu, A.R. and Sanyal, R.K. (New Delhi): Effects of Newer Glucocorticoids on Anaphylactic Shock in the Rat and the Mouse 593

Layton, L.L. (Albany, Cal.); Panzani, R. (Marseille) and Cortese, T.A.

(Indianapolis, Ind.): Coffee-Reaginic Human Sera Tested in Human

Volunteers and Macaque Monkeys. Absence of Reactions to Chlorogenic

Acid 417

Leach, G.D.H.: vide Hicks, R.

Leikola, J. (Helsinki): Quantitative Aspects of Mononucleosis Antibodies . . 105

Leikola, J. (Helsinki): Studies of Agglutinability of Bovine Red Cells .... 112

Contents

Levine, B.B $\cdot$ : vide Redmond, A. P.

LibPert, T. H. (Heidelberg) and Waton, N. G. (Glasgow): The Influence of

Chronic Histamine Treatment on Histamine Catabolism 292

Luhovyj, I.: vide Goodfriend, L.

Madalinski, K. (Warsaw) and Korngold, L. (New York, N.Y.): The Nature

of the Antigenic Site Responsible for the Detection of yM Globulins of

Type K or L with Antisera Specific for yM Globulins

327

McKneally, M. F.: vide Cooper, M. D.

Miescher, P.A.: vide Borel, Yves

Milgrom, F.; Humphrey, L.J.; Tönder, O.; Yasuda, J. and Witebsky, E.

(Buffalo, N. Y.): Antibody-Mediated Hemadsorption by Tumor Tissues 478

Milgrom, F.: vide Yasuda, J.

Mueller-Eckhardt, C.: vide Keller, R. 
Naspitz, C.K. (São Paulo); Eisen, A.H. and Richter, M. (Montreal): DNA Synthesis in vitro in Leukocytes from Patients with Ataxiã telangiectasia . . 217 Naspitz, C.K.; Blennerhassett, J. B.; Singhal, S.K. and Richter, M. (Mon treal, Quebec): The Action of Phytohemagglutinin in Rabbits. II. Histological Changes in Response to a 'Single' Intravenous Administration of Phytohemagglutinin 389

Naspitz, C.K. and Richter, M. (Montreal, Quebec): The Response of Human Peripheral Lymphocytes to Various Mitogenic Agents in vitro ..... 411

Nilsson, L.-Å. (Göteborg): Qualitative Analysis of Acute Phase Protein Antisera with the Comparative Interference Diffusion-in-Gel Technique .... 16

Okpako, D. T.: vide Hicks, R. Ovary, Z.: vide Bernstein, I.D.

Panzani, R.: vide Layton, L. L. Pekárek, J.: vide Castrová, Alexandra Perelmutter, L.: vide Goodfriend, L. Perey, D. Y.: vide Cooper, M. D. Pickering, R.J.: vide Gewurz, H. Radermecker, M. (Liège): Assessment of the Heterogeneity of Reagins Ac cording to Individuals and/or the Kind of Allergens 1

Redmond, A. P. and Levine, B.B. (New York, N. Y.): Delayed Skin Reactions to

Benzylpenicillin in Man 193

Richter, M.: vide Naspitz, C. K.

Richter, M.: vide Singhal, K.

Rose, N. R.: vide von Fellenberg, R.

Sanyal, R. K. (New Delhi): Chemical Mediators of Adrenaline-Induced Pul monary Oedema 59

Sanyal, R. K.: vide Arora, S. Sanyal, R.K.: vide Laddu, A.R.

Contents

Sapse, A.T.; Ivanyi, J.; Bonavida, B.; Stone, W. Jr.; Kramer, R. and Sercarz, E.E. (Los Angeles, Cal.): Tears as Carriers of Antibodies. II. Charge Heterogeneity of IgG Antibodies in Rabbit Tears 598

Schneider, C. H.: vide de Weck, A. L.

Scribner, Gertrude H.: vide Barboriak, J.J.

Sercarz, E.E.: vide Sapse, A.T.

Singhal, K. and Richter, M. (Montreal): Cells Involved in the Immune Re sponse. I. The Response of Normal Rabbit Bone Marrow Cells to Anti gens in vitro 493

Singhal, S. K.: vide Naspitz, C. K.

Smith, B.G.: vide Johnson, H.M.

Sorkin, E.: vide Blazkovec, A.A.

Sorkin, E.: vide Hulliger, L.

Stone, W. Jr.: vide Sapse, A.T.

Sutherland, D.E.R.: vide Cooper, M.D.

Tönder, O.: vide Milgrom, F. Tonutti, E.: vide Haferkamp, O.

Uppin, B.I.: vide Goldfarb, A.R.

Waton, N.G.: vide Lippert, T.H.

de Weck, A.L.; Schneider, C.H. and Gutersohn, J. (Bern): The Role of Penicilloylated Protein Impurities, Penicillin Polymers and Dinners in

Penicillin Allergy 535

West, G.B.: vide Csaba, B. 
Witebsky, E.: vide Hjort, T.

Witbbsky, E.: vide Milgrom, F.

Yasuda, J. (Osaka) and Milgrom, F. (Buffalo, N.Y.): Hemadsorption by Herpes Simplex-Infected Cell Cultures

151

Yasuda, J.: vide Milgrom, F.

Book Reviews 104, 207, 416, 610

News Items 104, 208, 614

Obituary

616 